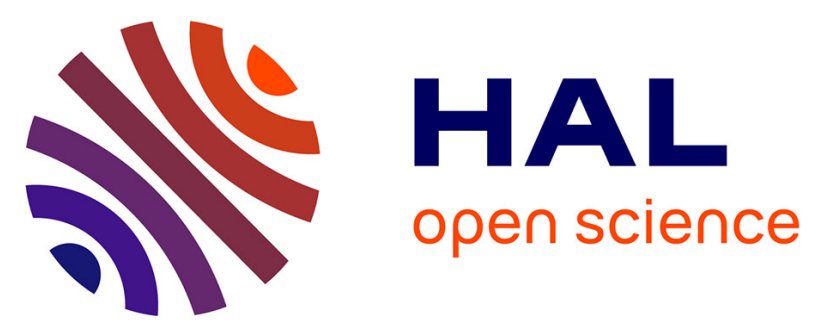

\title{
Simulation of enteric methane emissions from individual beef cattle in tropical pastures of improving quality: a case study with the model RUMINANT
}

Luciano Barreto Mendes, M. Herrero, P. Havlík, A. Mosnier, S. F. Balieiro, R. E. M. Moreira, M. Obersteiner

\section{To cite this version:}

Luciano Barreto Mendes, M. Herrero, P. Havlík, A. Mosnier, S. F. Balieiro, et al.. Simulation of enteric methane emissions from individual beef cattle in tropical pastures of improving quality: a case study with the model RUMINANT. Advances in Animal Biosciences, 2016, 7 (03), pp.233-234. 10.1017/S2040470016000248. hal-01607622

\section{HAL Id: hal-01607622 \\ https://hal.science/hal-01607622}

Submitted on 27 May 2020

HAL is a multi-disciplinary open access archive for the deposit and dissemination of scientific research documents, whether they are published or not. The documents may come from teaching and research institutions in France or abroad, or from public or private research centers.
L'archive ouverte pluridisciplinaire HAL, est destinée au dépôt et à la diffusion de documents scientifiques de niveau recherche, publiés ou non, émanant des établissements d'enseignement et de recherche français ou étrangers, des laboratoires publics ou privés.

\section{다(1)(2)}

Distributed under a Creative Commons Attribution - ShareAlikel 4.0 International 


\title{
Simulation of enteric methane emissions from individual beef cattle in tropical pastures of improving quality: a case study with the model RUMINANT
}

\author{
L. B. Mendes ${ }^{1 \dagger}$, M. Herrero $^{2}$, P. Havlík ${ }^{1}$, A. Mosnier ${ }^{1}$, S. F. Balieiro ${ }^{1}$, R. E. M. Moreira ${ }^{3}$ and \\ M. Obersteiner ${ }^{1}$
}

${ }^{1}$ Ecosystems Services and Management, International Institute for Applied Systems Analysis, Schlossplatz 1, A2351 Laxenburg, Austria; ${ }^{2}$ Agriculture Flagship, Commonwealth Scientific and Industrial Research Organization, Bioscience Precinct, 306 Carmody Road, St. Lucia, QLD, Australia; ${ }^{3}$ Center for Advanced Studies on Applied Economics, University of São Paulo, Av. Centenário, 1080, Piracicaba, São Paulo, Brazil

Keywords: herd structure, brachiaria, pasture quality, farm-scale modelling, seasonality

\section{Introduction}

Ruminant rearing activities are at the spotlight for reducing greenhouse gas (GHG) emissions (Gerber et al., 2013). In tropical regions, the culture of rearing ruminant herds in extensive pasture systems is usually associated with pristine forest degradation, which is another aggravating factor to climate change (Cohn et al., 2014). On the other hand, reducing GHG emissions from ruminants by decreasing herd size is unfeasible due to the continuous growth of human population, demand for food and assuming that current consumer behaviour and preference for meat and dairy products will persist in the future. One possible alternative to hamper GHG emissions from these systems is via optimisation, by, for instance, improving pasture quality. Better pastures will allow for improved productivity, and thus reduced enteric $\mathrm{CH}_{4}$ emissions per unit of produce (Hristov et al., 2013).

Albeit that most ruminants are reared in extensive or semi-extensive systems worldwide, little is known about quality of their pastures and their effects of weight gain and milk production. Expected influencing factors to pasture quality are soil physical, chemical and biological properties as well as soil nutrient balance, duration and intensity of the rainy season, temperature, pasture and herd management practices. Quantifying the effect of these pasture quality influencing factors on ruminant enteric $\mathrm{CH}_{4}$ emissions, would be advantageous to hamper emissions.

The aim of this research was to simulate enteric $\mathrm{CH}_{4}$ emissions from individual beef cattle, representative from tropical herds, and to evaluate the $\mathrm{CH}_{4}$ emission mitigation potential of improving pasture nutritional value.

\footnotetext{
${ }^{\dagger}$ E-mail: mendes@iiasa.ac.at
}

\begin{abstract}
Material and methods
The mechanistic model RUMINANT

The rumen dynamics model developed and described by Herrero et al. (2013) (RUMINANT) is used for this study. A detailed description of the equations and coefficients embedded in the model of Herrero et al. (2013) is provided in the studies of Illius and Gordon (1991) and Sniffen et al. (1992). Model input variables consists of current and target live body weights, maximum milk production and daily weight gain. Diet composition is picked from a built in library of 98 different types of feeds, classified as forages, concentrates and stovers. The main outputs of RUMINANT include daily faecal dry matter, urinal and nitrogen excretions, metabolisable energy above supply, supply above maintenance, potential milk production, live BW gain and enteric $\mathrm{CH}_{4}$ emissions.
\end{abstract}

\section{The study-case farm}

The characterisation of individual beef cattle used in the case of this study was made with information from Agri Benchmark database (Agri-Benchmark, 2016), the reference name of the farm is BR-400. This farm is physically located in the Brazilian state of Mato Grosso, at the edge of the Amazon forest. In order to define the amount of forage available to each individual cow, a herd of 1254 Nelore cows was considered. Animals graze year round at a pasture area of $2000 \mathrm{ha}$, yielding a stocking rate of $1.2 \mathrm{ha} / \mathrm{cow}$. The standard diet consists of ad libitum foraging with brachiaria, supplemented with salt minerals.

Model calibration and the low $\mathrm{CH}_{4}$ emission scenarios After calculations of manure production and enteric $\mathrm{CH}_{4}$ emissions for current feeding regimes (as described above), 
further simulations were conducted for different 'low emission' scenarios, aiming at reducing emissions by improving cattle diet quality.

\section{Results and discussion}

\section{Model calibration}

When paired together, the daily live weight gain (LWG) obtained from the model and that obtained for farm BR-400 fit to a linear model (Figure 1a). Linear regression analysis revealed that the data points presented a reasonable fit to the $45^{\circ}$ slope line, suggesting that the modelled data agreed fairly well with the field collected data. Daily LWGs were added to give total gains over the total number of days that each animal remained at a specific category, the data are presented in Figure 1b. The differences in total LWG between modelled and experimental data observed were as high as $36 \%$ (pregnant heifers), followed by heifers (34\%) and steers $(30 \%)$. However, the majority of the herd comprises weaners, lean and fat adult males, which presented relatively small disagreement $(0 \%$ to $17 \%)$.

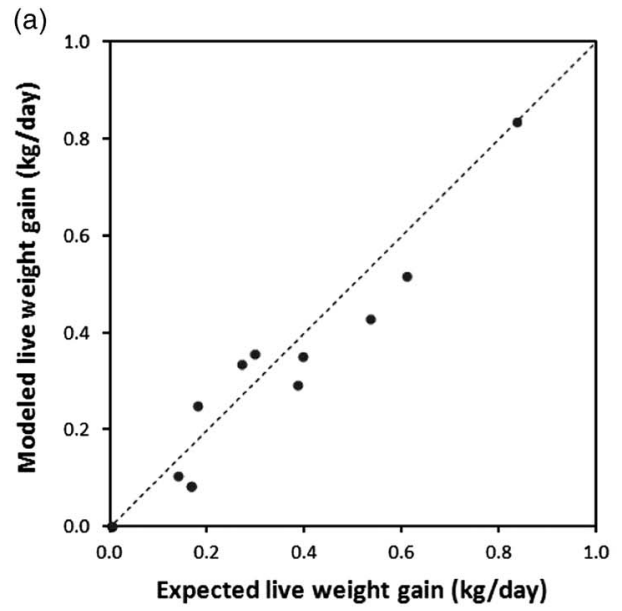

(b)

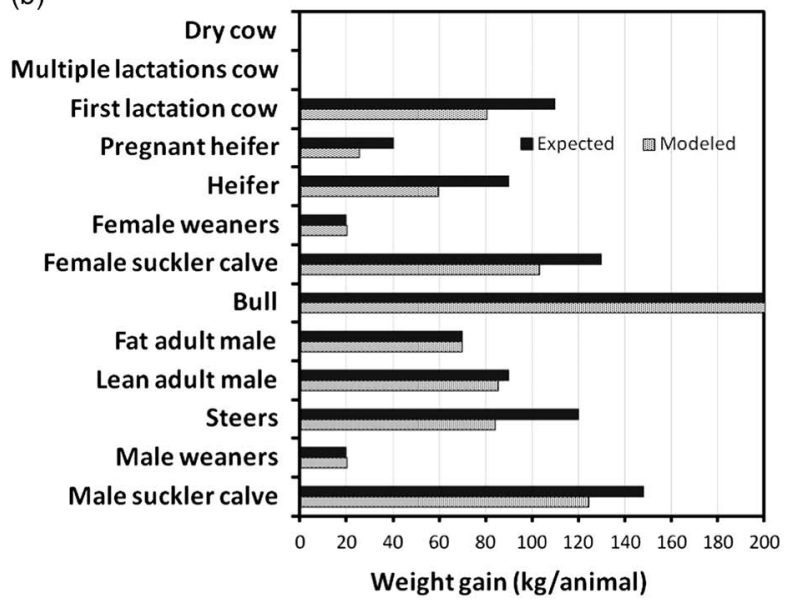

Figure 1 Comparison of modelled $v$. expected live weight gain (LWG, $\mathrm{kg} / \mathrm{day}$ ), where each data point represents an animal per category of the herd (a). LWG (kg/animal) over the designated period per herd category (b).
Table 1 Modelled enteric methane $\left(\mathrm{CH}_{4}\right)$ emissions (mean $\pm \mathrm{SE}$ ) at different scenarios of pasture quality pooled over the entire herd categories or considering beef cattle only

\begin{tabular}{lcc}
\hline \hline & \multicolumn{2}{c}{ Enteric $\mathrm{CH}_{4}$ emissions ${ }^{*}\left(\mathrm{~g} / \mathrm{kg}_{\mathrm{wg}}{ }^{* *}\right)$} \\
\cline { 2 - 3 } Scenario & Herd average & For beef cattle only \\
\hline Brachiaria summer & $0.99 \pm 0.31$ & $2.42 \pm 0.62$ \\
Brachiaria summer + sup. & $0.5 \pm 0.2(50 \%)$ & $0.48 \pm 0.12(80 \%)$ \\
Brachiaria winter & $0.33 \pm 0.06(66 \%)$ & $0.35 \pm 0.01(85 \%)$ \\
\hline \hline
\end{tabular}

* The number between brackets is the percentage of reduction in relation to the scenario 'brachiaria summer'.

**Per kg of live weight gained in a day.

\section{Scenario analysis}

Three scenarios were taken into account and the results are presented in Table 1. In the first scenario, or baseline, brachiaria is the main diet of the animals. This first scenario takes the dry conditions of the long-lasting summer in the Brazilian state of Mato Grosso (6 to 8 months/year) into account, leading to pasture of poorer nutritional value.

The next scenario took the same summer pasture into account, but with giving the animals a small supplementation with corn silage, leading to a reduction of the enteric methane emissions of at least $50 \%$, compared with the reference case. However, one must consider that supplementation is not the first option for the farmer when it comes to improvement of herd performance. The third scenario resulted of a reduction of enteric $\mathrm{CH}_{4}$ emissions of at least $66 \%$, during the winter, which is characterised by more rain. Similar emission reductions as in scenario 3 could be obtained by improving pasture management, such as dividing the pasture into patches for successive utilisation by the herd, intercalated with pasture resting periods.

\section{Acknowledgements}

The authors would like to thank IIASA for providing the funding, and 'agri benchmark' for providing the data used in this study.

\section{References}

Agri-Benchmark 2016. Agri Benchmark - beef and sheep. Retrieved on 13 January 2016 from http://www.agribenchmark.org/beef-and-sheep.html.

Cohn AS, Mosnier A, Havlik P, Valin H, Herrero M, Schmid E, O'Hare M and Obersteiner $M$ 2014. Cattle ranching intensification in Brazil can reduce global greenhouse gas emissions by sparing land deforestation. Proceedings of the National Academy of Science 111, 7236-7241.

Gerber PJ, Steinfeld H, Henderson B, Mottet A, Opio C, Dijkman J, Falucci A and Tempio G 2013. Tackling climate change through livestock - a global assessment of emissions and mitigation opportunities. FAO, Rome. pp. 1-139.

Herrero $M$, Havlik $P$, Notenbaert $A$, Rufino $M C$, Thornton $P K$, Blümmel $M$, Weiss F, Grace D and Obersteiner M 2013. Biomass use, production, feed efficiencies, and greenhouse gas emissions from global livestock systems. Proceedings of the National Academy of Sciences of the Unites States of America 110, 20888-20893.

Hristov AN, Ott T, Tricarico J, Rotz A, Waghorn G, Adesogan A and Dijkstra J 2013. Special topics - mitigation of methane and nitrous oxide emissions from animal operations: III. A review of animal management mitigation options. Journal of Animal Science 91, 5095-5113. 